\title{
Deteksi Kualitas Kuning Telur Ayam Kampung Menggunakan Ekstraksi Ciri Secara Statistika Orde Satu Berbasis Logika Fuzzy
}

\author{
Muhammad Sipan ${ }^{1)}$, Rony Kartika Pramuyanti ${ }^{2)}$ \\ ${ }^{1,2)}$ Program Studi Teknik Elektro, Fakultas Teknik, Universitas Semarang
}

\begin{abstract}
Chicken eggs have become a basic necessity for Indonesians, both for personal consumption and for business purposes. Eggs that are good or quality can be seen based on the yolk. Both those who are only a day old a week or more than two weeks or those that are not suitable for consumption.

Quality egg yolks appear brighter in yellow and there are no stripes or other colors and markings in the yolk. Eggs. From this, the author tries to do research on the detection of quality detection of native chicken egg yolk using Order One Statistical Extraction based on Fuzzy Logic. Feature extraction The first order egg yolk image in this study uses various features, namely variance, skewness, cartulation, entropy and mean. Texture measurements in the first order use statistical calculations based on the original image pixel value for the sole purpose of finding the histogram characteristics of the image.

The results of this study are the value of the feature calculation in first order statistics to be used to make the decision whether the egg yolk is suitable for consumption or not. This research is expected to be able to provide insight in determining the quality or absence of native chicken eggs. The first step in this research is to look for data in the form of egg yolks from native chickens, after that we take a picture in the form of an image of egg yolk using the same camera and the same distance as well. So that the image results obtained have the same level of precision. From this image, we then look for the first order statistical value which will be used as a reference in determining the quality of eggs using fuzzy logic.
\end{abstract}

Keywords: Egg yolk, order 1, extraction, Fuzzy Logic

Telur ayam sudah menjadi kebutuhan pokok bagi masyarakat Indonesia, baik untuk konsumsi pribadi maupun untuk keperluan bisnis. Telur yang baik atau berkualitas dapat di lihat salah satunya berdasarkan kuning telurnya. Baik yang baru berumur sehari seminggu maupun lebih dari dua minggu ataupun yang sudah tidak layak konsumsi.

Kuning telur yang berkuaitas tampak lebih cerah warna kuningnya dan tidak ada garis atau warna-warna lain dan berca dalam kuning telur tersebut. Telur Dari hal ini, penulis berusaha melakukan penelitian tentang deteksi Deteksi Kualitas Kuning Telur Ayam Kampung Menggunakan Ekstraksi Ciri Secara Statistika Orde Satu Berbasis Logika Fuzzy. Ekstraksi ciri Citra kuning telur secara orde satu pada penelitian ini mengggunakan berbagai ciri yang dimiliki yaitu variance, skewness, kartulasi, entropi dan mean. Pengukuran tekstur pada orde pertama menggunakan perhitungan statistic didasarkan pada nilai piksel citra asli semata dengan tujuan mencari karakteristik histogram yang dimiliki citra tersebut.

Hasil dari penelitian ini berupa nilai perhitungan ciri pada statististik orde satu akan digunakan untuk pengambilan keputusan kuning telur tersebut layak konsumsi atau tidak. Penelitian ini diharapkan mampu memberikan wawasan dalam menentukan kwalitas atu tidaknya telur ayam kampung. Langkah pertama yang dilakukan pada penelitian ini yaitu mencari data berupa kuning telur dari jenis ayam kampung, setelah itu kita ambil gambarnya berupa citra kuning telur dengan menggunakan kamera yang sama dan jarak juga posisi yang sama pula. Sehingga hasil citra yang diperoleh memiliki tingkat presisi yang sama. Dari citra tersebut kemudian kita cari nilai statistika orde satu yang nantinya digunakan sebagai acuan dalam penentuan kwalitas telur dengan menggunakan logika fuzzy.

Kata Kunci: Kuning Telur, orde 1, ekstraksi,Logika Fuzzy

\section{Pendahuluan}

$\mathrm{T}$ elur sudah menjadi kebutuhan pokok dalam kehidupan sehari-hari selain tempe untuk lauk pauk di lingkungan sekitar kita. Jenis telur juga bermacam macam ada telur ayam kampung, bebek ayam ras, telur asin telur panggang dan lain lain. Konsumsi telum semakin hari semakin meningkat, ini memiliki dampak postif maupun dampak negative dampak positif nya bagi supplier ini merupakan keuntungan yang besar akan tetapi dari pihak konsumen kita tidak tau telur yang kita konsumsi berkwalitas atau tidak. Karena ada beberapa alasan telur dapat dikatakan tidak berkwalitas atau tidak laya konsumsi.

Beberapa alsan tersebut misalkan telur sudah busuk, telur pada suhu yang panas sekali selama berhari-hari atau telur dalam kondisi basah dalam waktu yang lama. Telur yang berkwalitas atau tidak dapat kita lihat salah satunya dngan melihat kuning terlur tersebut. 
Berpedoman dengan permasalahan diatas Peneliti membahas bagaimana menentukan mendeteksi kuning telur menggunakan ektsraksi ciri statistika orde satu seperti variance, skewness, kartulasi,entropi dan mean untuk menentukan kwalitas telur ayam kampung berbasis logika fuzzy.

\subsection{Analisis tekstur}

Analisis tekstur digunakan untuk berbagai aplikasi untuk memecahkan masalah dan mecapai tujuan tertentu seperti untuk keperluan identifikasi, [2][3] klasifikasi [4][5], analisis citra medis[6], dan aplikasi yang lainya.

Beberapa pendekatan yag biasa digunakan untuk analisis tekstur, menurut Bharati[3] adalah metode statistikal, metode struktural, metode berbasis model, metode berbasis transformasi. Salah satu metode statistikal adalah Gray level co-occurance matriks (GLCM), yang digunakan pada penelitian ekstraksi fitur pada percobaan penelitian ini.

\subsection{Ekstraksi Ciri Statistik}

Ekstraksi ciri dilakukan untuk mendapatkan pola dari suatu citra yang akan dilatih maupun citra yang akan diuji. Metode ekstraksi ciri yang digunakan adalah ekstraksi ciri statistik. Metode ini menggunakan perhitungan statistik distribusi derajat keabuan (histogram) dengan mengukur tingkat kekontrasan, granularitas, dan kekasaran suatu daerah dari hubungan ketetanggaan antar piksel di dalam citra. Ekstraksi ciri statistik terbagi menjadi dua yaitu ekstraksi ciri statistik orde pertama dan orde kedua. Ekstraksi ciri orde pertama dilakukan melalui histogram citra. Ekstraksi ciri statistik orde kedua dilakukan dengan matriks kookurensi, yaitu suatu matriks antara yang merepresentasikan hubungan ketetanggaan antar piksel dalam citra pada berbagai arah orientasi dan jarak spasial.

Pada bagian kiri Gambar 1.1 Menunjukan histogram citra sebagai fungsi probabilitas kemunculan nilai intensitas pada citra. Bagian kanan merupakan hubungan ketetanggaan antar piksel sebagai fungsi orientasi dan jarak spasial, yang dimulai dari sudut $0^{\circ}$ sampai sudut $135^{\circ}$. Sisi atas kiri menunjukan jarak ketetanggan dengan sudut $0^{\circ}$, sisi kanan atas sudut $45^{\circ}$, sisi bawah kiri merupakan jarak spasial dengan sudut $90^{\circ}$, dan pada bagian kiri bawah adalah jarak spacsial dengan sudut $135^{\circ}$.

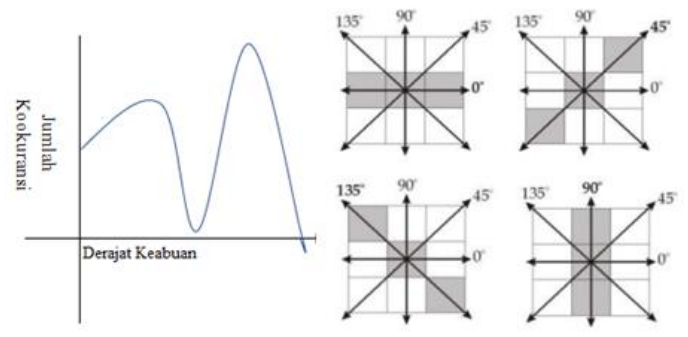

Gambar 1.1. Ilustrasi ekstraksi fitur statistic

\subsection{Ekstraksi Ciri Orde Pertama}

Ekstraksi ciri orde pertama merupakan metode pengamatan ciri yang didasarkan pada karakteristik histogram citra. Histogram menunjukkan probabilitas kemunculan nilai derajat keabuan piksel pada suatu citra. Dari nilai nilai pada histogram yang dihasilkan, dapat dihitung beberapa parameter ciri orde pertama, antara lain adalah mean, skewness, variances, kurtosis, dan entropy.

\section{a. Mean $(\mu)$}

Menunjukkan ukuran dispersi dari suatu citra.

$$
\mu=\sum_{n} f n P(f n)
$$

Dimana $f n$ merupakan suatu nilai intensitas keabuan, sementara $\mathrm{p}(f n)$ menunjukkan nilai histogram (probabilitas kemunculan intensitas tersebut pada citra).

\section{b. Variance $\left(\sigma^{2}\right)$}

Menunjukkan variasi elemen pada histogram dari suatu citra.

$$
\sigma^{2}=\sum_{n}(f n-\mu)^{2} P(f n)
$$

\section{c. Skewness ( $\alpha 3)$}

Menunjukkan tingkat kemencengan relatif kurva histogram dari suatu citra.

$$
\alpha 3=\frac{1}{\sigma^{2}} \sum_{n}(f n-\mu)^{2} P(f n)
$$

\section{d. Kurtosis}

Menunjukkan tingkat keruncingan relatif kurva histogram dari suatu citra.

$$
\alpha 4=\frac{1}{\sigma^{4}} \sum_{n}(f n-\mu)^{4} P(f n)-3
$$

\section{e. Entropy $(\mathrm{H})$}

Menunjukkan ketidakteraturan bentuk dari suatu citra

$$
\mathrm{H}=-\sum_{n} P(f n)^{2} \cdot \log p(f n)
$$

\section{Metode}

Penelitian ini menjelaskan tentang deteksi kuning telur ayam kampung dengan statistika orde satu berbasis logika fuzzy. Nilai-nilai statistik orde satu yang diperoleh digunakan sebagai acuan untuk menentukan citra kuning telur ayam kampung. Ciri orde satu yang digunakan aadalah, mean, skewness, variance, kurtosis, dan entropi. Ciri orde satu ini digunakan untuk menentukan kwalitas telur dengan deteksi citra kuning telur ayam kampung menggunakan ekstraksi ciri statistika 
orde satu berbasis logika fuzzy. Gambar 2.1 Menunjukan langkah-langkah penelitian, pertama merupakan citra kuning telur ayam kampung yang akan kita cari nilai statistiknya.

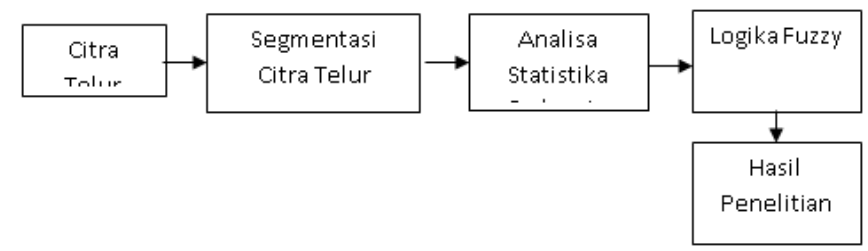

Gambar 2.1. Metode penelitian

Citra kuning telur direncakan akan di ambil dengan memphoto isi telur kampung sebanyak masing-masing 30 telur dengan menggunakan kamera Samsung A7. Setelah itu dari 30 citra kuning telur tersebut penulis segmentasi sehingga didapatkan citra yang terpisah antara kuning telur dan putih telur kemudian kita gunakan citra kuning telurnya. Pada langkah ketiga mencari nilai statisktik orde satu dari 30 kuning telur yang digunakan, Setelah didapatkan nilai-nilai tersebut kemudian nilai tersebut kita gunakan untuk menentukan kwalitas kuning telur ayam kampung berbasis logika fuzzy.

\section{HASIL DAN ANALISA}

Bab ini membahas hasil penelitian dan luaran yang dicapai dari pengujian yang telah dilakukan dengan beberapa alur yang dilakukan. Hasil yang akan di bahas adalah hasil penelitian yang berkaitan dengan nilai statistika orde 1pada citra telur, hasil pengambilan keputusan menggunakan logika fuzzy kemudian dari langkah tersebut digunakan sebagai acuan untuk menentukan kwalitas telur

\subsection{Data Penelitian}

Data penelitian yang digunakan sebanyak 20 buah citra yang terdiri dari 10 citra kuning telur Ayam Kampung dan 10 citra kuning telur Ayam Ras betipe JPG. Gambar 3.1 Menampilkan citra kuning telutr Ayam Ras dan Gambar 3.2 Menunjukkan citra kuning telur Ayam Kampung. Secara kasat mata warna kuning telur ayam ras lebih terang dang kuning telur ayam kampung lebih gelap atau memiliki warna yang lebih orange.

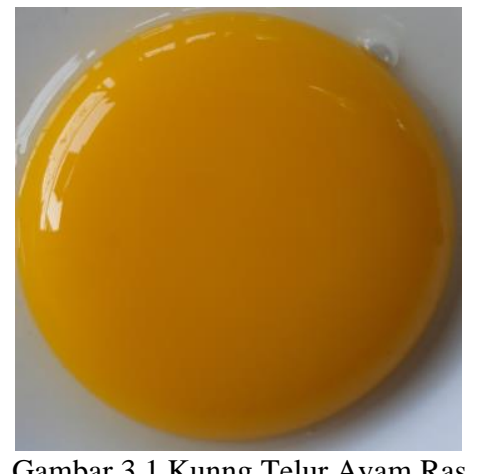

Gambar 3.1 Kunng Telur Ayam Ras

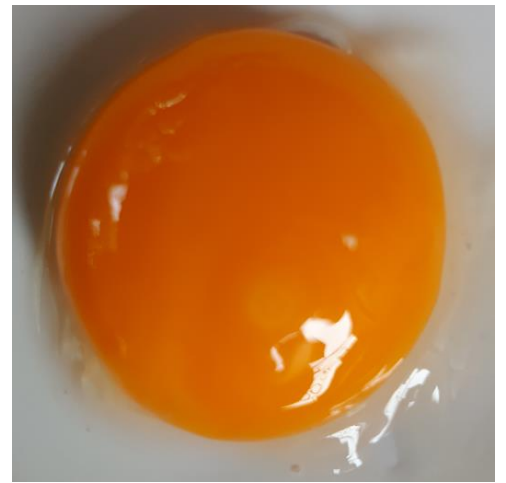

Gambar 3.2 Kuning Telur Ayam Kampung

\subsection{Ekstraksi Ciri Oede 1}

Penelitian ini menggunakan nilai statistika orde satu yaitu dengan ciri citra berupa mean, min, max, standar deviasi dan variance. Prosen penentuan titik-titik di tunjukan pada gambar 3.3. terdapat lima titik dengan koordinat berturut-turut posisi 2000, 1400; 2000, 1500; 2000, 1600; 2000, 1700; 2000, 1800 piksel.

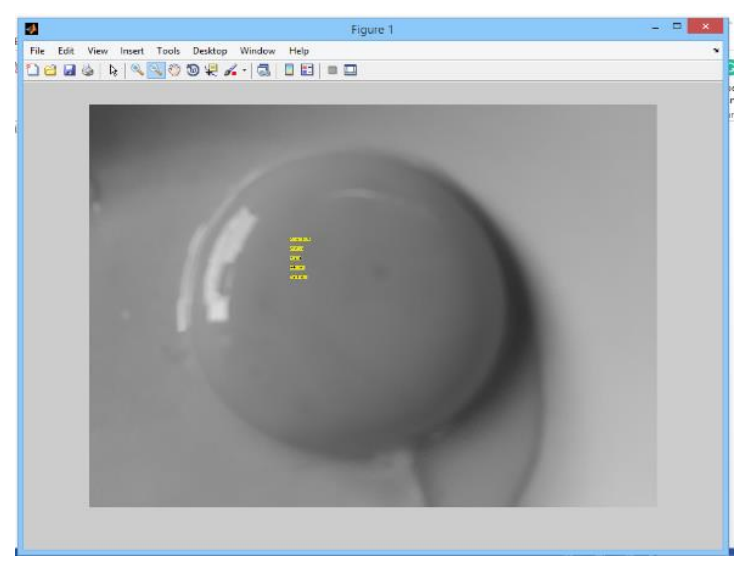

Gambar 3.3 Pengambilan koordinat kelima Ciri Ekstraksi yang Digunakan

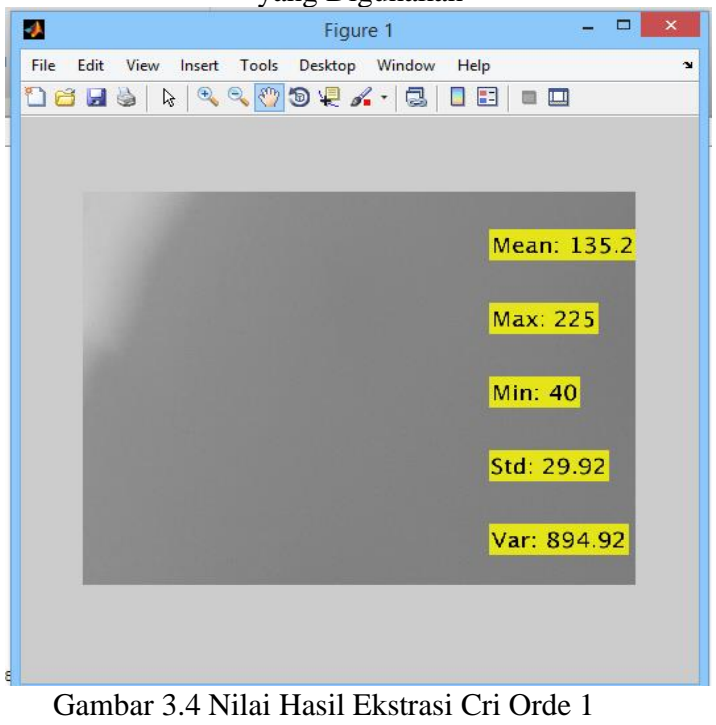

Gambar 3.4 Menunjukan kelima fitur ciri yang digunakan pada citra 20 yaitu dengan nilai mean sebesar 135.2, min 40, max 225. Standar deviasi 29.92 dan variance sebesar 894.92. nilai keseluruhan statistika ekstraksi ciri orde 1 dari hasil penelitian 
terdapat pada tabel 3.1 yang menjelaskan seberapa besar nilai dari kelima ciri yang dunakan tiap citra kuning telur.

Tabel 3.1 Nilai Statistik Ekstraksi ciri Orde 1

\begin{tabular}{|c|c|c|c|c|c|c|}
\hline Telur & Citra & Mean & Min & Max & Std & Var \\
\hline \multirow{10}{*}{ Ayam Ras } & 1 & 135.29 & 40 & 225 & 29.92 & 894.92 \\
\hline & 2 & 133.44 & 38 & 227 & 29.79 & 887.59 \\
\hline & 3 & 135.35 & 56 & 244 & 30.53 & 932.32 \\
\hline & 4 & 130.97 & 57 & 240 & 28.55 & 815.11 \\
\hline & 5 & 130.47 & 29 & 236 & 24.51 & 600.8 \\
\hline & 6 & 131.86 & 60 & 236 & 25.24 & 636.87 \\
\hline & 7 & 152.61 & 52 & 249 & 40.38 & $\begin{array}{r}1630.2 \\
8\end{array}$ \\
\hline & 8 & 153.17 & 47 & 251 & 38.98 & $\begin{array}{r}1519 \\
42 \\
\end{array}$ \\
\hline & 9 & 136.09 & 51 & 248 & 34.39 & $\begin{array}{r}1182.8 \\
5 \\
\end{array}$ \\
\hline & 10 & 132.51 & 50 & 246 & 32.25 & $\begin{array}{r}1040.2 \\
7 \\
\end{array}$ \\
\hline \multirow{10}{*}{$\begin{array}{c}\text { Ayam } \\
\text { Kampung }\end{array}$} & 11 & 138.26 & 78 & 255 & 34.81 & $\begin{array}{r}1211.8 \\
5 \\
\end{array}$ \\
\hline & 12 & 137.93 & 82 & 255 & 30.08 & 904.92 \\
\hline & 13 & 140.94 & 92 & 252 & 26.1 & 681.09 \\
\hline & 14 & 126.37 & 79 & 255 & 29.44 & 866.45 \\
\hline & 15 & 126.33 & 73 & 255 & 32.28 & $\begin{array}{r}1041.8 \\
7 \\
\end{array}$ \\
\hline & 16 & 125.4 & 78.255 & 255 & 28.86 & 833 \\
\hline & 17 & 140.34 & 51 & 255 & 32.26 & $\begin{array}{r}1040.8 \\
9 \\
\end{array}$ \\
\hline & 18 & 133.91 & 50 & 249 & 30.78 & 947.17 \\
\hline & 19 & 136.83 & 55 & 254 & 28.69 & 822.9 \\
\hline & 20 & 121.12 & 57 & 240 & 26.62 & 708.68 \\
\hline
\end{tabular}

Nilai terbesar yang di peroleh dari hasil uji coba masing-masing ciri ialah sebagai berikut mean sebesar 153.17 yaitu pada citra kuning telur ayam ras ke 8 , min terbesar di peroleh dari citra kuning telur ayam kampung ke 13 yaitu sebesar 92. Nilai max terbesar terdapat pada beberapa citra, yaitu pada citra ke 11, 12, $14,15,16,17$. Keenamnya citra kuning telur ayam kampung. Standar deviasi terbeasr terdapat pada citra kuning telur ke 7 yaitu citra kuning telur ayam ras dan variance terbesar adalah pada citra ke 7 sebesar 1630.27.

\subsection{Logika Fuzzy}

Dari uji coba yang dilakukan pada telur berdasarkan nilai-nilai statistika orde 1 yang di gunakan sebagai parameter metode fuzzy nilai, parameter yang digunakan adalah lima nilai dari mean varian, min, max dan Standart deviasis. Kelima nilai fitur atau ciri tersebut ditunjukan pada tabel 3.2 yang ada dibawah ini :
Tabel 3.2 nilai parameter yang di gunakan

\begin{tabular}{|c|l|c|r|r|c|r|}
\hline $\begin{array}{c}\text { Nilai } \\
\text { Statistika }\end{array}$ & \multicolumn{1}{|c|}{ Nilai } & Mean & Min & Max & Std & \multicolumn{1}{c|}{ Var } \\
\hline \multirow{2}{*}{$\begin{array}{c}\text { Ayam } \\
\text { Ras }\end{array}$} & Maksimal & 153.17 & 60 & 251 & 40.38 & 1630.28 \\
\cline { 2 - 7 } & Minimal & 130.47 & 29 & 225 & 24.51 & 600.8 \\
\hline $\begin{array}{c}\text { Ayam } \\
\text { Kampung }\end{array}$ & Maksimal & 153.17 & 92 & 255 & 40.38 & 1630.28 \\
\cline { 2 - 7 } & Minimal & 121.12 & 29 & 225 & 24.51 & 600.8 \\
\hline
\end{tabular}

Tabel 3.2 Menunjukan nilai maksimum dan nilai minimum pada masing-masing fitur yang digunakan dimana kelayakan konsumsi telur tersebut dari nilai statistika orde 1 berada pada nilai tersebut. Yaitu untuk nilai mean mulai 121.12 sampai 153.17 , nilai mean antara 29 sampai 92, nilai max antara 225 sampai 255 , nilai standart deviasi antara 24.51 sampai 40.38 dan nilai variance antara 600.8 sampai 1630.28

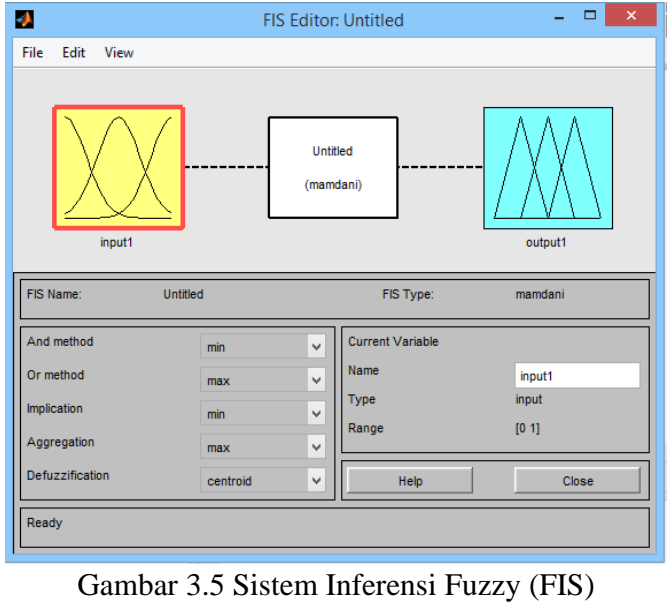

Gambar 3.5 Menunjukan system inferensi fuzzy, disini dijelaskan inputan, logika fuzzy dengan metode mamdani dan tampilan output. Gambar juga menjelaskan nama FIS yaitu metode penjumlahan, perkalian, implikasi, agrgregation dan defuzzification. Tipe FIS yang digunakan meliputi nama, tipe dan range nilai yang dignakan. Gambar 5.6 Menjelaskan tentang FIS pada ayam kampung dengan kelima parameter yang digunakan dan proses fuzzy menggunakan metode mamdani serta hasil kelayakan yang di peroleh.

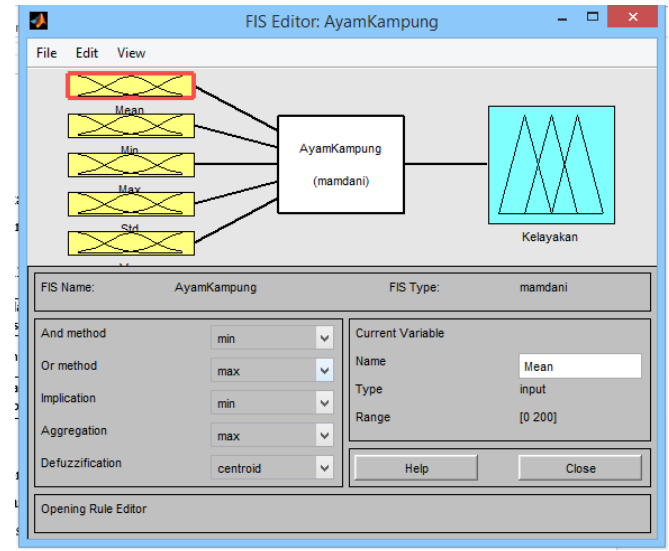

Gambar 3.6 Sistem Inferensi Fuzzy (FIS) untuk Ayam kampung 


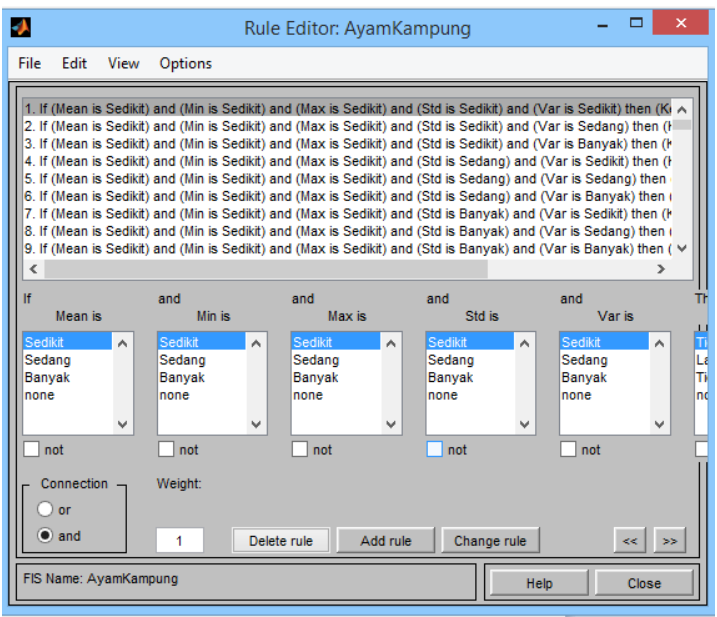

Gambar 3.7 Rule yang digunakan ayam kampung

Gambar 3.7 Berisi tentang hasil rule yang digunakan pada ayam kampung dimana jumlah rule nya sebesar $3^{5}$ dengan output layak atau tidak layak.

Gambar 3.8 Menjelaskan tentang FIS pada ayam RAS dengan kelima parameter yang digunakan dan proses fuzzy menggunakan metode mamdani serta hasil kelayakan yang di peroleh.

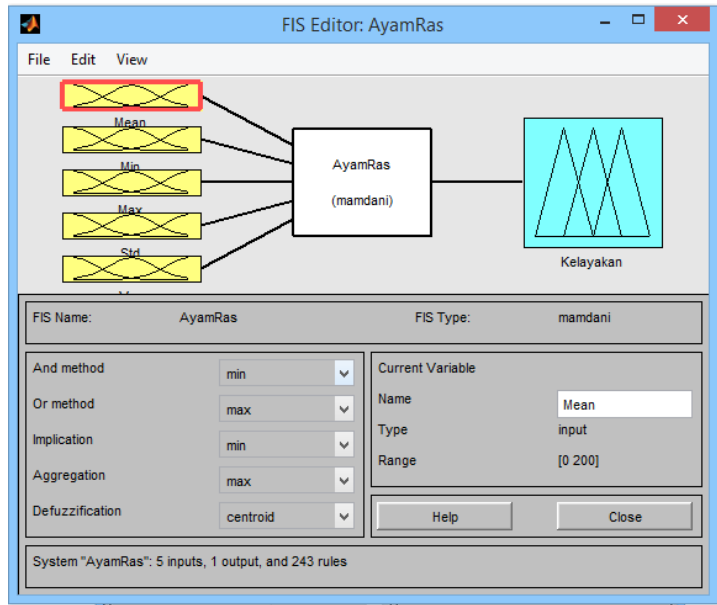

Gambar 3.8 FIS editor untuk Ayam RAS

Gambar juga menjelaskan metode penjumlahan, perkalian, implikasi, agrgregation dan defuzzification. Tipe FIS yang digunakan meliputi nama, tipe dan range nilai yang dignakan. Gambar 3.9 Berisi tentang hasil rule yang digunakan pada ayam kampung dimana jumlah rule nya sebesar $3{ }^{5}$ dengan ciri yang digunakan. Masing masing ciri terdapat tiga kondisi yaitu sedang, banyak dan sedikit. Hasil dari proses rule didapatkan keputusan output layak atau tidak layak.

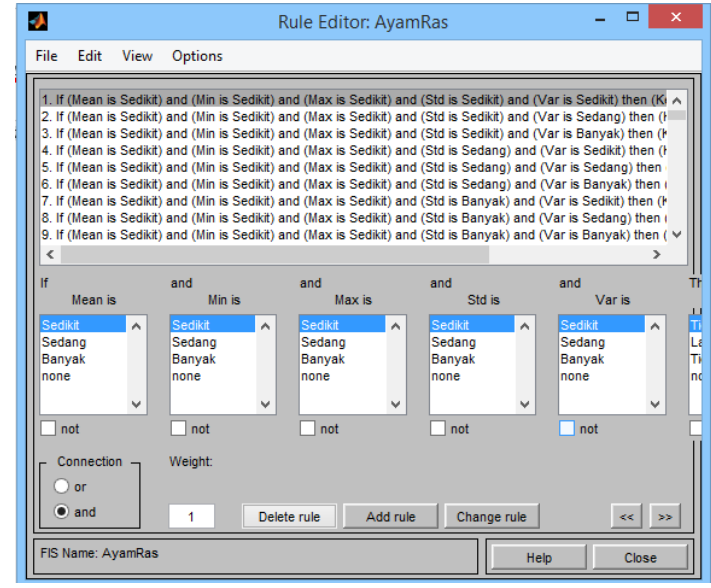

Gambar 3.9 Rule yang digunakan ayam kampung

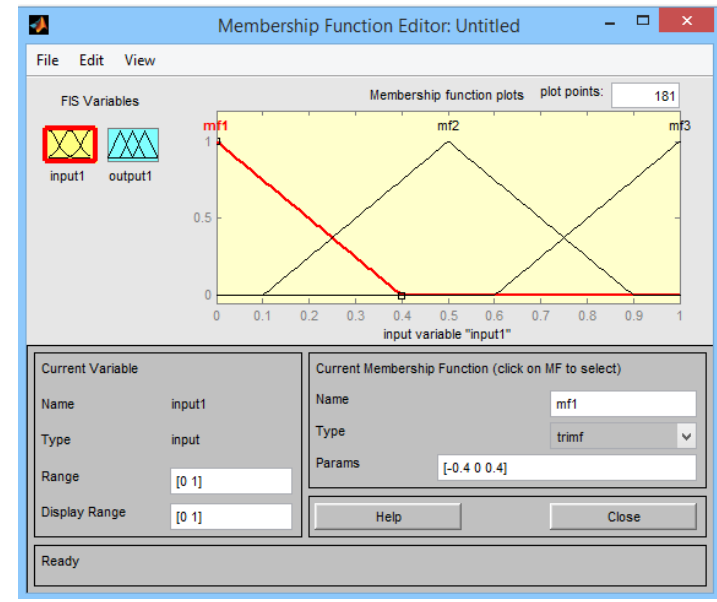

Gambar 3.10 FIS untuk Variabel input dan output

Gambar 3.10 Menjelaskan range nilai dari variable yang digunakan yaitu variable input dan output.

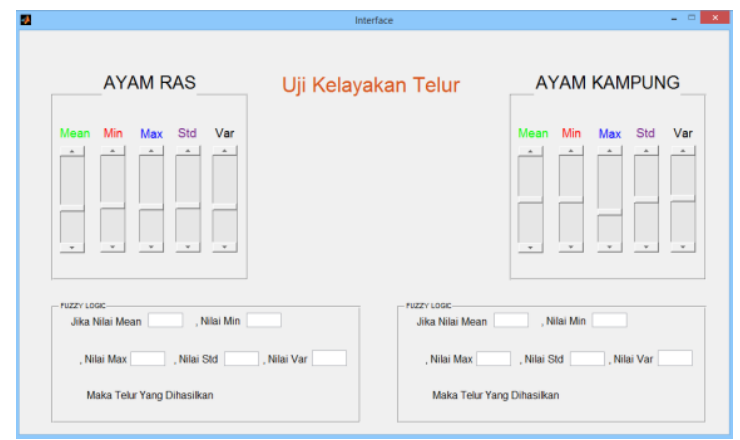

Gambar 3.11 Interface untuk kelayakan Telur Ayam kampung dan Ayam RAS

Interface pada pengujian kelayakan telur ayam terdapat pada gambar 3.11. beberapa tools yang di gunakan mean, min, max, std, var. pada penggunaan interface ini kita dapat mengubah-uabh nilai dari ciri yang digunakan sehingga pengambilan keputusan dapat di simpulkan yaitu telur layak atau tidak layak konsumsi. 


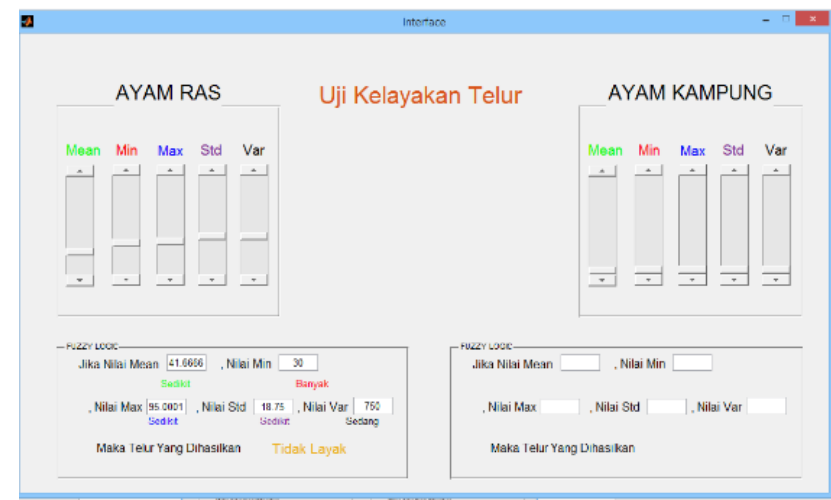

Gambar 3.12 Hasil Uji Coba Menggunakan Logika Fuzzy Pada Telur Ras

Hasil uji coba yang dilakukan untuk menentukan telur ayam kondisi layak atau tidak layak terdapat pada gambar 3.12 dan 3.13 Gambar 3.12 menjelaskan pengujian dari telur ras yang menunjukan telur pada kondisi tidak layak.

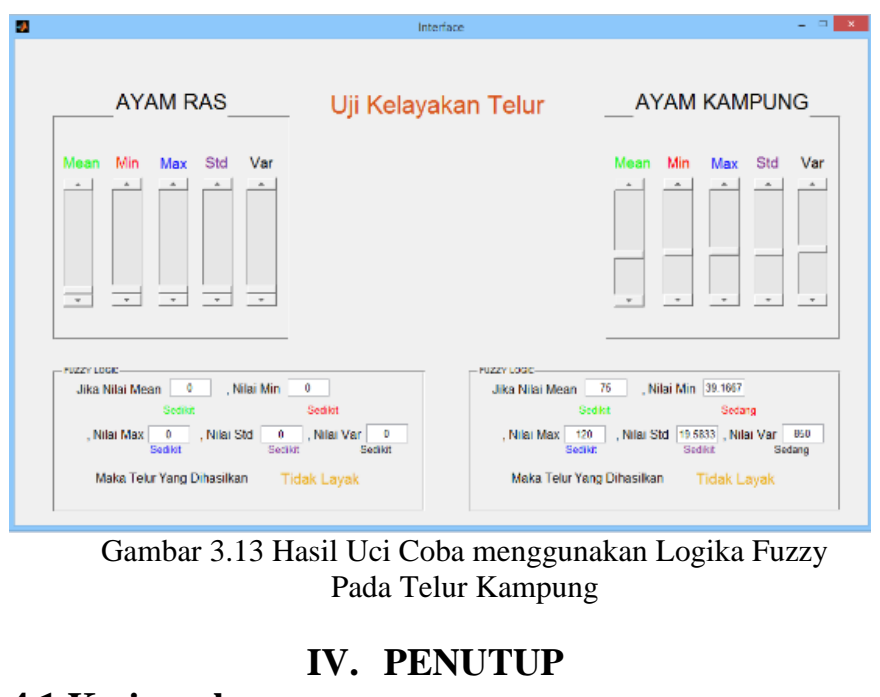

\subsection{Kesimpulan}

Nilai ciri yang digunakan pada pengambilan keputusan menggunakan logika fuzzy dengan metode mamdani untuk Ayam Ras sebesar mean antara 130.47 sampai 153.17 , min 29 sampai 60, max 225 sampai 251, standart deviasi, 24.51 sampai 40.38 dan variance 600.8 sampai 1630.28 . nilai kelayakan pada ayam kampung adalah mean 121.12 sampai 153.17 , min 29 sampai 92, max 225 sampai 255, standart deviasi 24.51 sampai 40.38 dan variance 600.8 sampai 1630.28.

Hasil uji coba kita dapat mengambil keputusan telur Ayam Ras dan Ayam Kampung tersebut layak atau tidak dikonsumsi menggunakan logika fuzzy berdasarkan ekstraksi ciri orde satu.

\subsection{Saran}

Hasil penelitian yang dilakukan, kesimpulan yang didapat, saran yang dapat penulis berikan untuk peneliti selanjutnya yaitu fitur ekstraksi ciri dapat diperbanyak untuk hasil pengambilan keputusan yang lebih presisi dalam mennyimpulkan kelayakan telur ayam kampung atau ayam ras. Disamping itu jumlah telur dapat ditambah sebagai data kedua citra dan penentuan tiik-titik ciri yang lebih banyak untuk dapat menghasilkan fitur atau ciri yang lebih variatif.

\section{Daftar Pustaka}

[1] Ahmad Muzami1), Oky Dwi Nurhayati2), Kurniawan Teguh Martono2) Aplikasi Identifikasi Citra Telur Ayam Omega-3 Dengan Metode Segmentasi Region Of Interest Berbasis Android. Jurnal Teknologi dan Sistem Komputer, Vol.4, No.2, April 2016 (e-ISSN: 2338-0403)

[2] Sipan Muhammad, Kartika Roni P. Analisis Tekstur Photo Lama Menggunakan Fitur Tekstur Gray Level Co-Occurrence Matriks Pada Pewarnaan Citra Otomatis' Semarang, 2017

[3]. Ustin Sousa, Rasoul Kabirzadeh, Patrick Blaes, "Automatic Colorization of Grayscale Images", Department of Electrical Engineering, Stanford University, 2013.

[4] Susanto adi, Kadir abdul, Teori dan aplikasi pengolahan citra,Penerbit andi, Yogyakarta. 2012

[5] Rahayu, I. H. (2003). Karakteristik Fisik, Komposisi Kimia dan Uji Organoleptik Telur Ayam Merawang Dengan Pemberian Pakan Bersuplemen Omega-3. Jurnal Teknologi dan Industri Pangan, Vol. XIV.

[6] Andre Wahyu Pratama, Hapsari Peni Agustin Tjahyaningtijas, Deteksi Tingkat Kejernihan Air Menggunakan Fuzzy Logic Berbasis Pengolahan Citra Sebagai Informasi Manajemen Perusahaan Air Minum, Teknik Elektro Telematika, Teknik, Universitas Negeri Surabaya. Jurnal Teknik Elektro. Volume 08 Nomor 03 Tahun 2019, 453 - 460

[7] Muhammad Sipan, Roni Kartika P, Ekstraksi Ciri Citra Kuning Telur Secara Statistika Orde Satu Untuk Mengenali Jenis Telur Ayam Ras Dan Ayam Kampung, LPPM universitas Semarang, 2019.

[8] Deptan. 2010. Tanya Jawab Seputar Telur Sumber Makanan Bergizi. Jakarta. http://www.deptan.go.id/pengumuman/nak032010/Booklet\%20Telur.pdf. Diakses 22 November 2010.

[9] Fibrianti, S.M., I. K. Suada, M. D. Rudyanto.2012.Kualitas Telur Ayam Konsumsiyang dibersihkan dan tanpa dibersihkan Selama Penyimpanan Suhu Kamar .Indonesia Medicus Veterinus 1(3):408- 416.

[10] Jazil, N., A. Hintono, S. Mulyani.2012.Penurunan Kualitas Telur Ayam Ras dengan Intensitas Warna coklat kerabang berbeda selama penyimpanan.Jurnal Aplikasi Teknologi Pangan 1(2): 43-47

[11] Cornelia, A., I. K. Suada, M. D. Rudyanto. 2014. Perbedaan Daya Simpan Telur Ayam Ras yang Dicelupkan dan Tanpa Dicelupkan Larutan Kulit Manggis. Indonesia Medicus Veterinus 3(2): 112-119.

[12] Argo. L. B. dan Mangisah. 2013. Kualitas Fisik Telur Ayam Arab Petelur Fase I Dengan Berbagai Level Azolla Microphylla. Animal Agricultural Journal, Vol. 2 No 1, 445-457.

[13] Anonim. 2010. Uji Kualitas Produk Telur. http://billyjoeadam.files.wordpress. com/ 2010/ 01/ telur. pdf. Diakses pada tanggal 25 Agustus 2010. 
[14] Jazil, N., A. Hintono, S. Mulyani. 2013. Penurunan kualitas telur ayam ras dengan intensitas warna coklat kerabang berbeda selama penyimpanan Jurnal Aplikasi Teknologi Pangan 2(1):43-47

[15] Dudusola, I. O. (2010).Comparative evalution of internal and external qualities of eggs from quail and guinea fowl. International research journal of plant science, 1, (5), 112- 115. 